体力科学(1995) $44,339 \sim 346$

\title{
エネルギー消典鼻からみた幼児の活動
}

\author{
王 昭 文 $^{*}$ 三村寛一** 平野久美子* $*$ 三上聡子*** \\ 米谷光弘 $* * * *$ 伊藤俊彦 $* * * * *$ 前田如矢 ${ }^{*}$

\section{ENERGY EXPENDITURE OF PHYSICAL ACTIVITY IN PRESCHOOL CHILDREN}

\author{
Chao-wen Wang, Kanichi Mimura, Kumiko Hirano, Satoko Mikami, \\ Mitsuhiro Yonetani, ToshihiKo Ito and KazUya MaEda
}

\begin{abstract}
The purpose of this study was to elucidate the relationship between the energy expenditure and the level of physical performance in preschool-age children. Seventy-six boys $(5 \sim 6$ years of age) had motor performance tests $(25 \mathrm{~m}$ run, soft-ball throw, standing-long-jump, Zig-Zag run, upright handstanding time, sit-and-reach, one-leg-balance). Twenty boys were divided into two groups. One consisted of ten boys as the superior group and the other ten boys as the inferior group in results of the motor performance tests.

Energy expenditure was calculated from oxygen intake measured by each child's $\mathrm{HR}-\mathrm{VO}_{2}$ regression equation in a treadmill running test and 24-hour heart rate measurement by monitoring recorder. Daily energy uptake was estimated from the weight and kind of food recorded by their parents.

Energy expenditure in kindergarten,at home and in one day for the superior group were found to be higher than those for the inferior group. Energy uptake in the superior group showed a significant-ly higher value than that in the inferior group. It can be concluded that the children of the superior group appeared to be more active, since test and monitoring measurements showed they had more energy expenditure and energy uptake.
\end{abstract}

(Jnp. J. Phys. Fitness Sports Med. 1994, $44: 339-346$ )

key words : Energy expenditure, heart rate, physical activity, energy uptake

\section{粕}

最近幼児の運動不足，エネルギー過㮃摃取が社 会的な問題となり，それが体力の低下，運動によ る外傷の增加, 小児の肥满傾向の増大, 小児成人 病の多発傾向などの要因として注目されている1. 7.8.9.10.15.17.24.31)。これらの問題は幼年期の健康で

*大阪市立大学

于558 大阪市住吉区杉本3-3-138

${ }^{* *}$ 大阪教育大学 厂582 大阪府柏原市旭が丘4-698-1

****阪教育福祉専門学校 于544 大阪市生野区林寺2-21-13

****西南学院大学

T814 福岡市早良区西新6-2-92

******阪Y MC A松尾台幼稚園

于666-02 兵庫県川辺郡猪名川町松尾台2-2-2
あるだけでなく,加齢による発育・発達を障害し， 成人期に達したのちまでも影響する可能性があ る.この問題を解決するためには，幼児の日常生 活において適度の運動習慣をもたせることが必要 であり，しかも至適運動量がどの程度のものであ るか検討しておかねばならない4,18).

従来から幼児の活動量に関する研究では,
Osaka City University, 3-3-138

Sugimoto, Sumiyoshi-ku, Osaka, 558

Osaka University of Education, 4-698-1,

Asahigaoka, Kashiwara-city, Osaka

Osaka College of Education and Welfare, 2-21-13

Hashitera, Ikuno-ku, Osaka, 544

Seinan Gakuin University, 6-2-92,

Nishijin, Saware-ku, Fukuoka-shi, 814

Osaka YMCA Matsuodai Kindergarten, 2-2-2,

Matsuodai, Inakawa-chome, Kawanabegun, Hyogoken 
Hovell ら ${ }^{11)}$ の行動記録によるもの, Shephard ら 28$)$ の質問用紙及び行動記録によるもの, Saris ${ }^{27)} の$ 万歩計によるものが報告されている．最近では， 心拍数から推定値による日常生活の運動量の測定 が多く使われており ${ }^{2,12,13,14)}$ ，心拍数から運動強 度を推定するもの, 日常生活の運動量の測定など が報告されている $20,21,22,23)$ 。またBradfield $5^{5,6)}$, 沼尻 ${ }^{25)}$, 菅原 ${ }^{29)}$, 青木ら ${ }^{3)}$, 山本 ${ }^{30)}$, Mitchell ${ }^{19)}$ は心拍数からエネルギー消費量を推定している. しかし，現在のところ幼児における一日の運動量 をエネルギー消費量の面から検討した研究はみあ たらない.

そこで, 本研究は 5 ～ 6 歳の幼稚園園览を対象 に安静時(仰臥位, 座位, 立位)の心拍数, 酸素捸 取量とトレッドミル漸増負荷法による最大下及び 最大酸素攝取量, 24 時間心拍数の連続測定および 行動観察法により一日のエネルギー消費量を算出 し, 運動能力テスト, エネルギー摄取量との関連
などについても検討した.

\section{研究 方 法}

川西市私立Y幼稚園に在籍する 5 ～ 6 歳の年長 男児76名を対象に, 運動能力テスト 7 項目 $(25 \mathrm{M}$ 走, ソフトボール投げ, 立ち幅跳び, ジグザグ走, 体支持持続時間, 開眼片足立ち, 長座体前屈)を 実施した. 更に 3 項目 $(25 \mathrm{M}$ 走, ソフトボール投 げ，立ち幅跳び)での総合結果をもとに対象を上 位10名の上位群, 下位10名の下位群の 2 群に分け て対比した．対象の年齢，身長，体重などの身体 的特徴及び運動能力テストの結果を表 1 に示し た。

1. 安静時テスト及び運動負荷テスト

安静時の心拍数, 酸素攝取量を測定ために, 幼 児には30分間の座位安静後, マットの上で仰臥位 (3 分間)，座位 ( 3 分間)，立位 ( 3 分間)を行い, 平均心拍数, 酸素攝取量は 3 段階で得られた値の

Table 1. Physical Characteristics of the Subjects

\begin{tabular}{|c|c|c|c|c|c|}
\hline & \multicolumn{2}{|c|}{$\begin{array}{l}\text { Superior } \\
\qquad(N=10)\end{array}$} & \multicolumn{3}{|c|}{$\begin{array}{l}\text { Inferior } \\
\quad(N=10)\end{array}$} \\
\hline & Mean & SD & & Mean & SD \\
\hline Age $(y r)$ & 5.8 & 0.3 & & 5.6 & 0.2 \\
\hline Height (cm) & 116.5 & 3.5 & & 113.2 & 5.0 \\
\hline Weight (kg) & 20.9 & 1.9 & & 20.0 & 2.6 \\
\hline Chest Girth (cm) & 56.6 & 1.6 & & 55.6 & 3.1 \\
\hline Sitting Height $(\mathrm{cm})$ & 64.4 & 2.5 & & 62.2 & 2.3 \\
\hline Kaup's Index & 15.3 & 0.8 & & 15.6 & 2.1 \\
\hline \multicolumn{6}{|c|}{ Impedance - Nakadomo et al. (1991) } \\
\hline Fat $(x)$ & 14.8 & 2.6 & * & 18.4 & 4. 7 \\
\hline Fat (kg) & 3.1 & 0.6 & & 3.8 & 1. 4 \\
\hline $\operatorname{LBM}(k g)$ & 17.8 & 1.7 & * & 16.2 & 1.6 \\
\hline \multicolumn{6}{|l|}{ Motor Performance } \\
\hline $25 \mathrm{~m}$ run $(\mathrm{sec})$ & 6.1 & 0.4 & $* * *$ & 6.9 & 0.5 \\
\hline soft-ball throw(m) & 8.9 & 1.2 & $* * *$ & 5. 1 & 1.1 \\
\hline standing - l ong-jump (cm) & 119.0 & 11.4 & $* * *$ & 93.8 & 11.8 \\
\hline Zig-Zag run (sec) & 15.5 & 0.8 & * & 16.4 & 1.0 \\
\hline U. H.T. (sec) & 61.6 & 54.5 & & 38.9 & 15.2 \\
\hline sit-and-reach (cm) & 5.3 & 5.0 & & 4. 8 & 5.4 \\
\hline one-leg-balance (sec) & 69.3 & 47.7 & & 64.0 & 54.3 \\
\hline
\end{tabular}

U. H. T : Upright Handstanding Time

${ }^{*} \mathrm{p}<0.05$

$* * \mathrm{p}<0.01$

$* * * p<0.001$ 
平均値とした. 又, 各個人の心拍数一酸素摂取量 の関係を明かにするために, トレッドミルによる 歩行及び走行による多段階漸増負荷法による運動 負荷テストを実施した。運動負荷は(1) $2.7 \mathrm{~km} / \mathrm{h}$

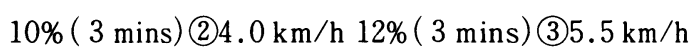
$14 \%$ ( $3 \mathrm{mins}$ ) (4) $7.0 \mathrm{~km} / \mathrm{h} 16 \%$ ( $1 \mathrm{~min}$ ) $57.0 \mathrm{~km} / \mathrm{h}$

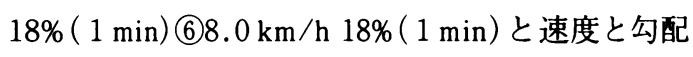
を漸増させて, 幼巟が exhaustionに達するまで 実施した。酸素摂取量はエアロモニター(ミナト 医科学, AE-10)を用いて測定し, 心拍数は双極 胸部誘導法によるテレメーター法により得られた 心電図より記録した。各負荷段階で得られた各個 人の心拍数と酸素摂取量との関係を最小自乗法に よって直線回帰し, 心拍数一酸素摂取量の関係式 を求めた。

\section{2. 心拍数の連続測定}

心拍数は携帯用心拍数記憶装置 (VINE 社製)を 対象20名に登園後に装着させ, 翌日までの24時間 を連続して記録した. 尚, 心拍数の測定と併せて, あらかじめ用意した用紙を用いて対象の行動観察 を実施した。

\section{3. 覚醒時エネルギー消費量の算出}

覚醒時エネルギー消費量は覚醒時の毎分心拍数 を安静時テスト，運動負荷テストで得られた平均 值及び関係式に代入することによって推定した. 又, 消費された酸素 $1 l$ を $4.9 \mathrm{kcal}$ として, それ ぞれの值をエネルギー消費量とした。

\section{4. 睡眠エネルギー消費量の算出}

睡眠中の心拍数から酸素消費量の計算ができな いので, 体重当たり $6.5 \mathrm{ml} / \mathrm{kg} / \mathrm{min}$ の值を用い $\tau^{26)}$, 対象の体重, 睡眠時間に応じて睡眠中の 酸素消費量を計算した。 また酸素消費量から睡眠 エネルギー消費量を算出した。

\section{5. エネルギー攝取量の測定}

食物攝取量調查は 24 時間心拍数を測定した前後 3 日間において実施した。エネルギー摄取量は捸 取食物の献立や食品別に捸取重量をもとに第 4 次 食品標準成分表を用いて算出した ${ }^{16)}$ 。なお，食 物摂取量の秤量記入は各対象の母親に依頼した.

\section{結果}

1. 安静時テスト及び運動負荷テストにおける 心拍数と酸素消費量

表 2 は対象の安静時テスト, 運動負荷テストの 結果を示したものである. 安静時 3 段階平均 $\dot{\mathrm{V}} \mathrm{O}_{2}$ については上位群と下位群の間に有意な差 が認められなかったが, 平均心拍数は上位群が下 位群より少なく，両群の間で有意な差が認められ た $(\mathrm{P}<0.05)$. 絶対値 $\mathrm{V}_{2} \max$ についてみると上 位群は816.0 $1355.0 \mathrm{ml} / \mathrm{min}$ の範囲で平均 $1063.6 \pm 135.4 \mathrm{ml} / \mathrm{min}$ 下位群は $752.0 \sim 995.0$ $\mathrm{ml} / \mathrm{min}$ の範囲で平均 $882.5 \pm 78.2 \mathrm{ml} / \mathrm{min}$ を示し

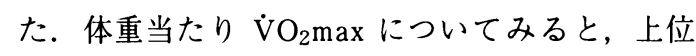
群は 43.0 $58.7 \mathrm{ml} / \mathrm{kg} / \mathrm{min}$ の範囲で平均 $51.1 \pm$

Table 2. Heart Rate and Oxygen Uptake during Tests

\begin{tabular}{|c|c|c|c|c|c|}
\hline & \multicolumn{2}{|c|}{$\begin{array}{l}\text { Superior } \\
\qquad(N=10)\end{array}$} & \multicolumn{3}{|c|}{$\begin{array}{l}\text { Inferior } \\
(N=10)\end{array}$} \\
\hline & Mean & SD & & Mean & SD \\
\hline \multicolumn{6}{|l|}{ Test at Rest } \\
\hline$H R(b p m)$ & 99.9 & 7.4 & * & 109.3 & 11.1 \\
\hline Vं $02(m 1 / m$ i n $)$ & 167.0 & 21.5 & & 165.0 & 19.6 \\
\hline \multicolumn{6}{|l|}{ Treadmill Test } \\
\hline$H R m a x(b p m)$ & 199.2 & 8.3 & & 195.8 & 9.8 \\
\hline$\dot{\mathrm{V}} 02 \mathrm{max}(\mathrm{m} \mathrm{l} / \mathrm{m}$ in $)$ & 1063.6 & 135.4 & $* * *$ & 882.5 & 78.2 \\
\hline$\dot{\mathrm{v}} 02 \mathrm{max} / \mathrm{m}(\mathrm{ml} / \mathrm{kg} / \mathrm{m}$ in $)$ & 51.1 & 5.6 & ** & 44.7 & 5.0 \\
\hline
\end{tabular}


$5.6 \mathrm{ml} / \mathrm{kg} / \mathrm{min}$, 下位群は $33.1 \sim 51.3 \mathrm{ml} / \mathrm{kg} / \mathrm{min}$ の範囲で平均 $44.7 \pm 5.0 \mathrm{ml} / \mathrm{kg} / \mathrm{min}$ を示した。す なわち, 絶対值及び体重当たり $\mathrm{VO}_{2} \max$ とも上 位群のほうが大きい值を示した $(\mathrm{P}<0.001$, 0.01).トレッドミル運動負荷テストにより得ら れた心拍数と酸素摂取量との相関関係は上位群, 下位群とも $\mathrm{r}=0.968 \sim 1.000(\mathrm{P}<0.001 \sim 0.01)$ の 範囲で高い有意な相関が認められ, 心拍数が運動 強度を示す指標として利用し得ることが示唆され た。

\section{2. エネルギー消費量}

\section{【一日】}

一日のエネルギー消費量については，上位群が $1240.0 \sim 1851.0 \mathrm{kcal}$ の範囲で平均 $1523.1 \pm$ $205.3 \mathrm{kcal}$, 下位群が $1130.2 \sim 1513.4 \mathrm{kcal}$ の範 囲で平均 $1265.4 \pm 108.7 \mathrm{kcal}$ を示し，両群の間 で統計的に有意な差が認められた $(\mathrm{P}<0.01)$.

\section{【園生活】}

表 3 は幼稚園生活を(1)屋内の自由遊び(2)屋外の 自由遊び(3)屋内の授業(4)屋外の授業(5)昼食の 5 つ
の時間帯に区分し, 心拍数, エネルギー消費量, 時間を示したものである。このことから，園生活 は 4 時間 40 分〜 5時間51分の範囲で平均 5 時間 21 分を過ごし, 一日の $22.3 \%$ 占め, 平均心拍数 は上位群で $120.9 \pm 4.4 \mathrm{bpm}$ 下位群で $119.4 \pm$ $9.2 \mathrm{bpm}$ を示した。エネルギー消費量は上位群で $563.0 \pm 131.7 \mathrm{kcal}$ 下位群で $385.2 \pm 65.8 \mathrm{kcal}$ を 示し, 両群の間で統計的に有意差が認められた $(\mathrm{P}<0.01)$.

図 1 は園生活の指導内容別に時間あたりのエネ ルギー消費量を示したものである．そのうち，エ ネルギー消費量が最も高かったのは体育教師によ る体育授業であった．上位群は 76.7 ～ 199.4 $\mathrm{kcal} / \mathrm{h}$ の範囲で平均 $139.0 \pm 35.0 \mathrm{kcal} / \mathrm{h}$, 下位群 は $72.0 \sim 128.3 \mathrm{kcal} / \mathrm{h}$ の範囲で平均 $98.7 \pm 19.2$ $\mathrm{kcal} / \mathrm{h}$ を示し, 両群の間で統計的に有意な差が 認められた $(\mathrm{P}<0.01)$.

【家庭生活】

表 4 は家庭生活を(1)屋内の自由遊び(2)屋外の自 由遊び(3)その他の 3 つの時間帯に区分し, 心拍数,

Table 3. Mean and Standard Deviation of Five Types of Activities in Kindergarten

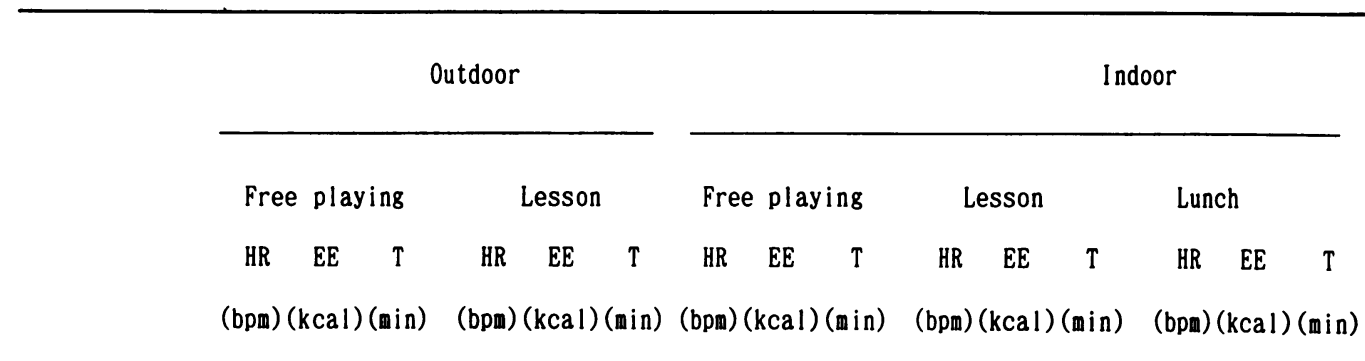

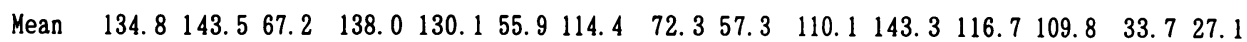
Superior

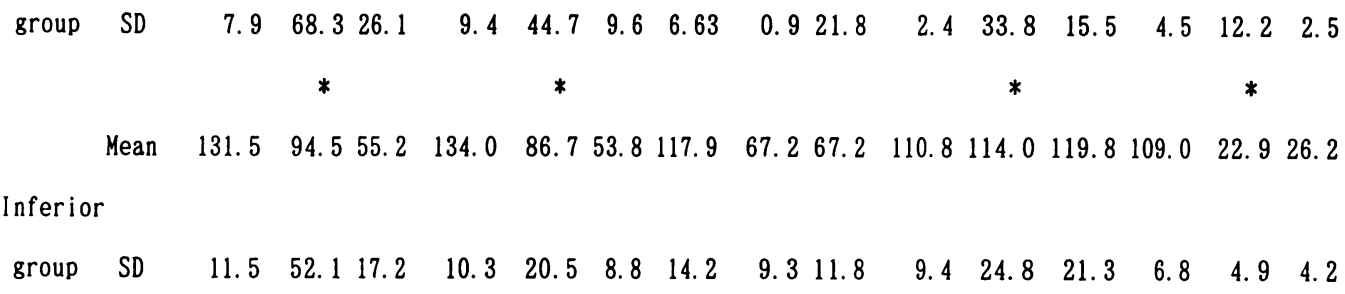
HR : Heart Rate $\quad$ EE : Energy Expenditure $\quad T$ : Time $\quad{ }^{*} p<0.05$ 


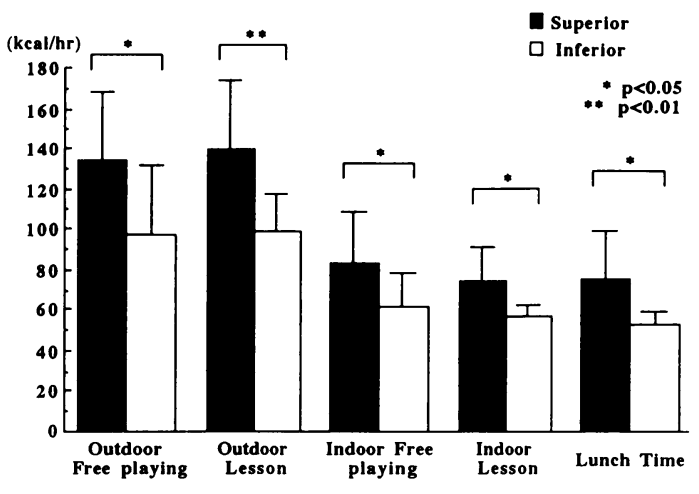

Fig. 1. Energy Expenditure per Hour of Five Types of Activities in Kindergarten

Table 4. Mean and Standard Deviation of Three Types of Activities at Home

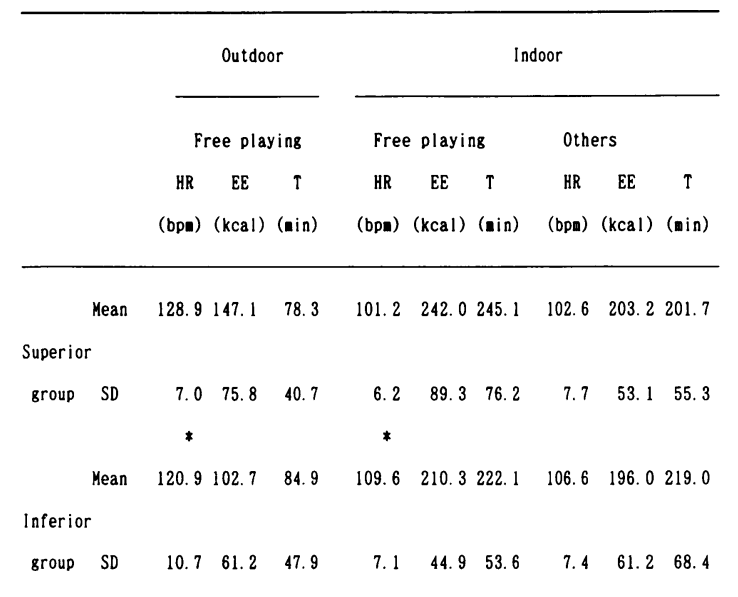

HR : Heart Rate EE : Energy Expenditure

$\mathrm{T}$ : Time

${ }^{*} \mathrm{p}<0.05$

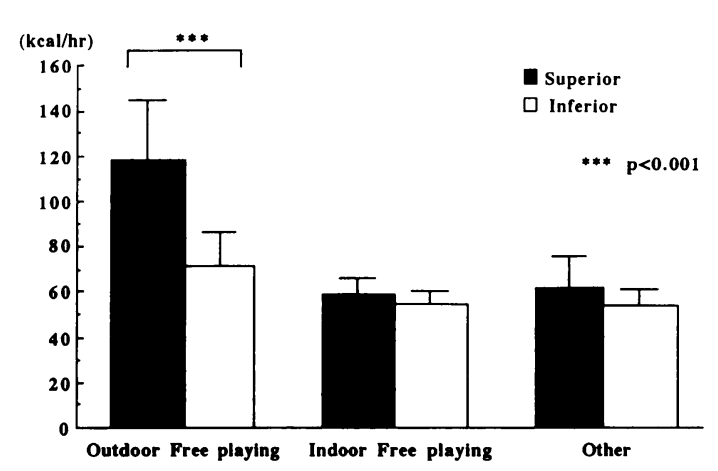

Fig. 2. Energy Expenditure per Hour of Three Types of Activities at Home
エネルギー消費量, 時間を示したものである。こ のことから，家庭生活は 7時間55分～10時間 6 分 の範囲で平均 8 時間 45 分を過ごし，一日の $36.4 \%$ を占め, 平均心拍数は上位群で $107.6 \pm 7.3 \mathrm{bpm}$, 下位群で $110.3 \pm 8.0 \mathrm{bpm}$ を示した. エネルギー 消費量は上位群で $592.4 \pm 83.8 \mathrm{kcal}$, 下位群で $500.0 \pm 66.0 \mathrm{kcal}$ を示し, 両群の間で統計的に有 意差が認められた $(\mathrm{P}<0.05)$.

図 2 は家庭生活内容別に時間あたりのエネル ギー消費量を示したものである。そのうち，最も 差が大きかったのは屋外の自由遊びであり, 上位 群で平均 $118.7 \pm 26.1 \mathrm{kcal} / \mathrm{h}$ であり, 下位群で 平均 $71.4 \pm 15.2 \mathrm{kcal} / \mathrm{h}$ であった $(\mathrm{P}<0.001)$.

\section{【睡眠】}

睡眠は 8 時間37分〜10時間54分の範囲で平均 9 時間54分を過ごし，一日の $41.3 \% を$ 占め，平均心 拍数は上位群で $78.5 \pm 4.7 \mathrm{bpm}$, 下位群で 82.6 $\pm 6.7 \mathrm{bpm}$ を示した。エネルギー消費量は上位群 で $394.7 \pm 37.7 \mathrm{kcal}$, 下位群で $380.2 \pm 45.0 \mathrm{kcal}$ を示したが，両群の間は統計的に有意差が認めら れなかった。

\section{3. エネルギー摄取量}

三日間の一日平均エネルギー摂取量についてみ ると, 上位群が $1437.6 \sim 1983.0 \mathrm{kcal}$ の範囲で平 均 $1683.6 \pm 144.1 \mathrm{kcal}$, 下位群が 968.5 1719.4 $\mathrm{kcal}$ の範囲で平均 $1506.7 \pm 218.1 \mathrm{kcal}$ を示し, 両群の間で統計的に有意な差が認められた $(\mathrm{P}<$

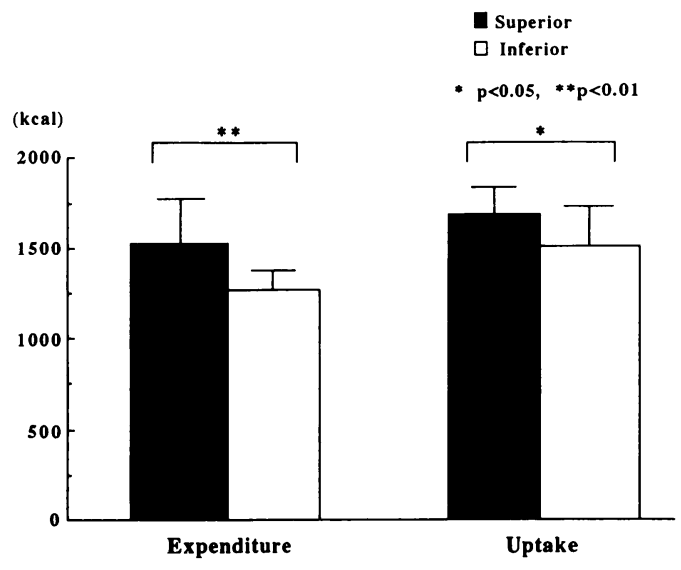

Fig. 3. Energy Expenditure and Energy Uptake in a 24-hour day 
$0.05)$.

図 3 は上位群, 下位群の一日の平均エネルギー 消費量・撕取量を示したものである。エネルギー バランスについては正の値を示したものが上位群 10 名中 6 名, 下位群 10 名中 9 名, 負の値を示した ものが上位群 10 名中 4 名, 下位群 10 名中 1 名で あった.

\section{考察}

従来から, $\mathrm{V}_{2} \max$ は体力, 特に呼吸循環器系 の指標として用いられており, 今回の上位群の平 均値は $1063.6 \pm 135.4 \mathrm{ml} / \mathrm{min}(51.1 \pm 5.6$ $\mathrm{ml} / \mathrm{kg} / \mathrm{min})$, 下位群の平均値は $882.5 \pm 78.2$ $\mathrm{ml} / \mathrm{min}(44.7 \pm 5.0 \mathrm{ml} / \mathrm{kg} / \mathrm{min})$ を示し, 上位群の 方が大きい值を示した。 また，これらの值は吉沢 ら ${ }^{31)}$ の 5.5 歳 $922 \mathrm{ml} / \mathrm{min}(48.7 \mathrm{ml} / \mathrm{kg} / \mathrm{min}), 6.0$ 歳 $1004 \mathrm{ml} / \mathrm{min}(48.1 \mathrm{ml} / \mathrm{kg} / \mathrm{min})$, 吉田ら ${ }^{22)}$ の 6.3 歳 $801.2 \mathrm{ml} / \mathrm{min}(38.3 \mathrm{ml} / \mathrm{kg} / \mathrm{min})$ の值に比し て大きい値を示した.

一般に, 日常生活の実際の消費量は日常生活時 の心拍数の記録と負荷テスト時の心拍数一酸素攝 取量関係式から推定されている3 5,6,19,25,29,30). 特に幼児については青木ら ${ }^{3)}$ の 4 〜 歳の年中幼 稚園児の 6 名を対象に園生活におけるエネルギー 消費量を算出した報告がみられるにすぎない，今 回の $5 \sim 6$ 歳の年長幼稚園園児の一日エネルギー 消費量は上位群が平均 $1523.1 \pm 205.3 \mathrm{kcal}$, 下位 群が平均 $1265.4 \pm 108.7 \mathrm{kcal}$ を示し, 上位群が 有意に高い値を示した $(\mathrm{P}<0.01)$. また, 覚醒時 エネルギー消費量は, 上位群が $1128.4 \pm 199.8$ $\mathrm{kcal}$, 下位群が $885.2 \pm 85.5 \mathrm{kcal}$ で, 両者に有意 な差が認められた. 特に, 園生活の屋外の自由遊 びにおいて，大きな差が認められた。よく活動す る子どもは，自由にかつ自主的に活動する時間が 比較的多い家庭生活において特によく活動してお り,運動習慣がつくことにより運動能力 (走・投 · 跳)が優れている傾向があると考えられる.

内容別の時間あたりのエネルギー消費量につい てみると, 上位群では幼稚園, 家庭いずれもエネ ルギー消費量が高い. しかし，下位群では, 幼稚 園あるいは家庭での室内活動にほとんど変化がみ
られない(表 2,3 より). また, 上位群では幼稚 園での屋外自由遊び時間 $(67.2 \pm 26.1 \mathrm{~min})$ の方が 室内自由遊び時間 $(57.3 \pm 21.8 \mathrm{~min})$ より長いが, 下位群では $55.2 \pm 17.2 \mathrm{~min}$ と $67.2 \pm 11.8 \mathrm{~min}$ と 上位群と比して逆な值を示した。このことから幼 稚園でも家庭でも外へ出して遊ばせれば十分エネ ルギーを消費できるが, 下位群では, 単に外に出 しただけでは効果が少なく, 適切な指導により初 めて十分なエネルギー消費に導くことができるこ とが示唆された.

昼食時のエネルギー消費量は, 上位群が 33.7 $\pm 12.2 \mathrm{kcal}$, 下位群が $22.9 \pm 4.9 \mathrm{kcal}$ であった。 この原因は上位群が興奮して他の子供と話した り, 立ったり座ったりしていて, 安静時テストよ り高い心拍数を得たものと考えられる.

一方, 厚生省 ${ }^{16)}$ によって示された 5 ～ 6 歳巟 の一日の栄養所要量は $1600 \sim 1700 \mathrm{kcal}$ である. 本研究の上位群 $(1683.6 \pm 144.1 \mathrm{kcal})$ が厚生省基 準の上限を满たし，下位群 $(1506.7 \pm 218.1 \mathrm{kcal})$ が $100 \mathrm{kcal}$ 不足の值を示した. しかし，上位群 の平均エネルギー消費量は $1523.1 \pm 205.3$ で $160.6 \mathrm{kcal}$ の超過でしかないが, 厚生省基準より $100 \mathrm{kcal}$ 不足である下位群の平均エネルギー消費 量は $1265.4 \pm 108.7 \mathrm{kcal}$ で平均 $241.3 \mathrm{kcal}$ で上 位群より多い。また，事実正のバランスをとった 者は上位群に 6 名, 下位群 9 名である。栄養と運 動は健康維持・増進にとって, 適切なバランスが とれていることが大切である.このことから，幼 児の運動量を確保するという面で, 学校と家庭が 協力し, 特に屋外の自由遊びに対する指導者, 親 の理解と積極的な推進が必要であることが示唆さ れた。

\section{要約}

幼児の健全な成長, 発育を促し, 運動量, 摄取 量の資料を得るために, 運動能力テストの上位, 下位各10名の幼稚園男子園児 $(5 \sim 6$ 歳) を対象 に，一日のエネルギー消費量を心拍数，酸素摄取 量から推定することと一日の食物摄取状況調査を 実施し，結果は次の通りである。

1. 最大酸素摄取量は上位群で $1063.6 \pm 135.4$ 
$\mathrm{ml} / \mathrm{min}(51.1 \pm 5.6 \mathrm{ml} / \mathrm{kg} / \mathrm{min})$ ，下位群で 882.5 $\pm 78.2 \mathrm{ml} / \mathrm{min}(44.7 \pm 5.0 \mathrm{ml} / \mathrm{kg} / \mathrm{min})$ を示し, 上 位群のほうが大きい傾向を示した。

2. 一日のエネルギー消費量は上位群が $1523.1 \pm 205.3 \mathrm{kcal}$ ，下位群が $1265.4 \pm 108.7$ kcal 下位群がであった。下位群は活動量が少な い傾向を示した。

3. 園生活の指導内容別にみると, エネルギー 消費量が最も高かったのは体育教師による体育授 業であった。上位群は $76.7 \sim 199.4 \mathrm{kcal} / \mathrm{h}$ の範 囲で平均 $139.0 \pm 35.0 \mathrm{kcal} / \mathrm{h}$, 下位群は 72.0 $128.3 \mathrm{kcal} / \mathrm{h}$ の範井で平均 $98.7 \pm 19.2 \mathrm{kcal} / \mathrm{h}$ を 示した.

4. 家庭生活内容別のうち, 最も差が大きかっ たのは屋外の自由遊びであり, 上位群で平均 $118.7 \pm 26.1 \mathrm{kcal} / \mathrm{h}$ であり, 下位群で平均 71.4 $\pm 15.2 \mathrm{kcal} / \mathrm{h}$ であった。

5. エネルギー摂取量と消費量のバランスにつ いては正の値を示したものが上位群10名中 6 名, 下位群10名中 9 名であった。肥満の予防と積極的 な健康づくりには食事を減じるのではなく，運動 を増やすべきである。

(受付 平成 6 年 4 月 11 日)

\section{考文献}

1) 青木純一郎, 村岡 功 子どもと運動不足, 体育 科学, (1978), 26, 23-25.

2) 青木純一郎, 村岡 功, 石河利寛 幼児体育教室 の運動強度, 体育科学, (1979), 7, 173-176.

3）青木純一郎, 石河利寛, 村岡 功, 吉田敬義 幼 稚園保育中のエネルギー消費量,体育科学, (1981),

9, 195-200.

4）浅見高明, 渋川㑆二, 石島 繁 幼览の適正運動 量に関する研究一幼稚園におけるトレーニング中 の運動強度とエネルギー消費量について一，体有 科学, (1983), 11, 106-116.

5) Bradfield R. B. A technique for determination of usual daily energy expenditure in the field. Am. J. Clini, Nuturi., (1971), 24, 1148.

6) Bradfield R. B., J. Paulos, M. S. and L. Guossman, M. A. Energy expenditureand heart rate of obese high school girls. Am. J. Clini, Nuturi., (1971), 24,
1482.

7) Dietz, W. H. Childhood obesity: Susceptibility, cause, and managiment. J. Pidiatr., (1983), 105, 676-685.

8）藤沢良知 子どものヘルシー食事学一子どもの食 生活指針一 初版, 第一出版, 東京, (1989), 5-11.

9）原 まどか, 青木継稔 小児の肥満と成人病, 臨 床栄養, (1987)，76，1990

10）日比逸郎 子どもの肥満と成人病の若年化, から だの科学，(1988)，141，93-95

11) Hovell, M. F., J. H. Bursick, R. Sharkey and J. Mcclure, A evaluation of elementary students voluntary physical activity during recess. Ress. Quart.,(1978), 49, 460-474.

12）加賀谷淳子 幼览の運動生活, 体育の科学, (1972), 22,386-391.

13）加賀谷淳子 幼児の運動活動と体力, 体育の科学, (1975)，25, 530-536.

14）加賀谷淳子, 横関利子 幼肾の日常生活の運動量, 体育の科学, (1981)，31，245-252.

15）衣笠昭彦 小児の肥満, 臨床栄養, (1987), 71, 156-161.

16）厚生省保健医療局健康增進栄養課編 第 4 次改訂 日本人の栄養所要量, 初版, 東京, (1990), 8-40.

17）松浦義行 子どもの生活と運動不足, 体育の科学, (1981)，31，245-252.

18）松浦義行 幼览における至適運動量の検討一健康 度と運動能力に対する日常の運動習慣の相対的関 連度について一, 体育科学, (1984), 12, 106-117。

19) M. Mitchell Energy intake and expenditure in chil dren of various degrees of obesity. A pilot study performed at the Children's Exercise and Nutrition Centre, Hamioton, as part of research elective, (1988)

20）三村寛一, 佐藤光子, 辰本頼弘, 伊藤俊彦, 野村 至弘, 渡辺完児, 田中喜代次, 前田如矢 幼览の 園生活における運動強度に関する研究 (第 4 報)一 トレッドミル運動負荷テストー, 大阪教育大学紀 要, (1988), 37, 57-66.

21）三村寛一，渡瀬剛行，西村民生，清水伸行,伊藤俊彦 幼児の園生活における運動強度に関する研究 (第 2 報)一保育環境の違いによる心拍数の変動一, 大阪 教育大学紀要, (1985)，34，171-180 
22）三村宽一, 辰本頼弘, 佐藤光子, 前田如矢 幼児 の園生活における運動強度に関する研究 (第 5 報) 一睡眠中の心拍数変動について一, 大阪教育大学 䄫要, (1988)，37, 183-169.

23）三村宽一，上林久雄 幼坚の日常生活における至 適運動量に関する基礎的研究一 24 時間の心拍数の 変動について一, 体力科学, (1985), 34, 201-210.

24) Muooins, A. G. The prognosis in juvenile obisity. Arch. Dis. child., (1958), 33, 307-314.

25）沼尻幸吉 エネルギー代謝と心拍数との相関につ いて, 労働科学, (1974), 50, 79.

26) Roy J. Shephard Physiology and biochemistry of exercise. praeger special studies. praeger scientific, (1987)

27) Saris. W. H. M and R. A. Binkhors The use of pedometer and actometer in studying physical in man Part 1 : Reliability of pedometer and actometer, Eur. J. Apol. Physiol., (1977), 37, 219-228.
28) Shophard, R. J., C. Jequire. H. Lova-llee, R. LaBarre and M. Pajic. Habitual physical activity: effect of sex milien, season and required activity, J. Sport. Med., (1980), 20, 55-66.

29）菅原正志 心拍数からみたエネルギー消費量の推 定に関する研究, デサントスポーツ科学, (1981), 1, 149-154.

30）山本高司, 北川薰, 坪内伸司, 加藤好信, 朝比奈 一男 小学生男子(11歳)の 1 日の消費エネルギー 量, 体育科学, (1983), 11, 63-68.

31) 吉沢茂弘, 石崎忠利, 本多宏子 $3 \sim 6$ 歳览の最 大酸素攝取量, 体育学研究, $(1980), 25,58-68$

32）吉田敬義, 石河利寛 呼吸循環機能からみた幼児 の持久走について, 体育学研究, (1978)，23, 59-65

33) Wolf, O. H. Obisity in childhood and its effects. Postgrad, Med. J., (1962), 38, 629-635. 